\title{
The Effect Of Church Community Development And Pastoral Services On The Growth Of The Congregation Of The Bethel Indonesia Church, Family Blessing Surabaya
}

\author{
Kasiatin Widianto $^{1)}$, Surja Permana ${ }^{2)}$, Juanda ${ }^{3)}$ \\ ${ }^{1)}$ Evangelical Theological Seminary of Indonesia - Surabaya \\ E-mail: widianto@sttii-surabaya.ac.id \\ ${ }^{2)}$ Evangelical Theological Seminary of Indonesia - Surabaya \\ E-mail: surjapermana@sttii-surabaya.ac.id \\ ${ }^{3)}$ Evangelical Theological Seminary of Indonesia - Surabaya \\ E-mail: juanda@sttii-surabaya.ac.id
}

\begin{abstract}
The existence of the church in this world is God's plan and will. Like a plant, which naturally grows and develops; as is the case with the existence of the church, God desires that His church grow and develop both in quality and quantity. There are various factors that influence the growth of the church, including the presence of church members and good pastoral care for the people. This research to describe the influence of church building and pastoral care on the growth of the congregation of the Bethel Indonesia Church "Family Blessing" Surabaya. Apart from that, to find out how much influence each independent variable has on the dependent variable.

The approach used in this research is quantitative; where the population which is the object of this research is 400 members of the Bethel Indonesia Church "Family Blessing" Surabaya. The sample is taken from a population of $24 \%$ or 96 people who can represent the population with a simple random sampling technique. The data collection technique uses an instrument in the form of a questionnaire to collect data on three variables, namely: (1) fostering church members, (2) pastoral care, and (3) church growth. The results of the study showed: (1) the influence of coaching church members on the growth of the congregation of the Bethel Indonesia Church "Family Blessing" Surabaya was in the medium category. (2) the influence of pastoral care on the growth of the congregation of the Bethel Indonesia Church "Family Blessing" Surabaya in the medium category. And (3) the influence of coaching church members and pastoral care together on the growth of the congregation of the Bethel Indonesia Church "Family Blessing" Surabaya is also in the medium category. Based on the findings in this research, several suggestions were suggested as follows: (1) The formation of church members, with three dimensions, namely Coinonia, Diakonia and Marturia had influence in the medium category. It is recommended that it be maintained, even if the implementation is increased. Because through these three dimensions the resources of the people are included in the ministry. (2) As with the formation of church members, pastoral care also influences the moderate category of church growth, therefore it is recommended that the implementation be increased so that through direct contact with the life of the congregation it will strengthen the spirituality of the church.
\end{abstract}

Keywords: Church Fostering, Church Growth, Pastoral Care

\section{INRODUCTION}

Church is the fourth institution formed by God himself. The first is family, the second is government, the third is the establishment of the nation of Israel as God's people, and the last is the church. The church has many similarities with other institutions, its existence is unique in its birth, plans, missions and goals. The word "Church" is a Portuguese word for taking: igreja, which comes from the

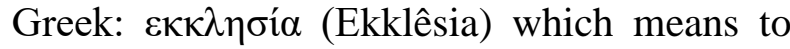
be called out.

Etymologically the word church is

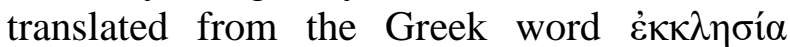
(ekklesia); comes from the words ek (out) and 
kalleo (calling). The word "ekklesia" is also interpreted from the use of the word "ek" to mean: get out of a group of people. "Specifically this word is used to describe a group of people who are called out for specific and definite purposes. The word ekklesia is usually used to describe a group of people, both formal and informal associations or associations, who sometimes only gather together as a mass (Acts 19:32, 39, 41). And these associations are usually in a political sense and not in a religious sense. Added, the word does not explain the person, but about the meeting. So, a church based on the term "ekklesia" is a meeting of people who are called out of a collection to a new collection to achieve a common goal in a designated place. The church or "ekklesia" which is also often referred to as the congregation does not mean that the gathering which is carried out is based on one's own desire to gather, but it is Christ who through the Word and the Spirit gathers for Him the congregation."

The term church, in English Church, and called by the word Kirk (Dutch) and Kirche in German does not originate from the word ekklesia but from the word Gerika kuriakon which means it belongs to God. This word emphasizes that the Church belongs to God. The word is only used twice in the New Testament; first used for Holy Communion (1 Cor. 11:20) and second for the Lord's Day (Rev. 1:10). Thus it can be given an additional definition of the term "church" which is: a group of people who have been called out of the world and belong to God. Thus, the church or "ekklesia" experiences a more specific meaning that refers to a special collection called Christians, namely a collection of people called by Christ who died on the cross out of darkness because of sin to the miraculous light of Christ through the word with the help of the Holy Spirit.

So, the church is not referring to the building as defined by some people. The church is an individual who is also called a "living organism", that is, everyone who believes in the gospel, Jesus, who joins together to unite in a place that has been determined together by carrying out religious ceremonies, which are the fellowship ceremony with God. The church is a collection of people who God has called out from this world to be His own, God's own people. God calls them in and through Jesus Christ.
The church as a community of people who have been called from the darkness to enter the kingdom of Jesus Christ (Col. 1:13), more than that the church is people who are called to fellowship with one another and fellowship with God in Jesus Christ. Theologically, the definition of the church as a fellowship of believers, because what has united them is their belief and or faith in God who revealed themselves in Christ Jesus, and this is what is called the Christian faith as the human response to God. As people who have been saved by the grace of God in Christ Jesus, who have been justified in spite of being sinners, all of which are accepted by man through faith.

The word 'church' / 'ekklesia' in the Old Testament comes from the original word 'qahal' (Hebrew), which means 'collection of people', or translated in the LAI Bible as 'congregation' (Num. 19:20; $20: 4$, Deut 23: 1-4, Neh 13: 1, Ps 22:22, 26, 26:12, 35:18, 40:10, 68:27, 89: 6, 149: 1; Prov 5:14; Lam 1:10; Joel 2:16). This 'qahal', or 'group of people' or 'congregation', is in the context of Greek and Jewish society an association formed on the basis of worship, based on on juridical or political unity. In the context of the Old Testament, this 'group of people' refers to the assembly of God to whom God had made a covenant, marked by the Sinai covenant under the leadership of the Prophet Moses. The covenant of this church (the Israelites) with God was marked by the blood of the Passover lambs which freed them from Egyptian slavery, and for 40 years later received manna bread from heaven before entering the Promised Land. This group of people is God's chosen people who have survived, even though the following centuries were scattered, experienced exile in Babylon, restoration during the time of the prophet Ezra, until the time of the New Testament. Not unlike the institutions established both by the government and private, both in the country and institutions that exist abroad, the founder certainly and surely wants that the institution he has formed is not stagnant or stagnant, but growing and moving advanced. Likewise God wants the church to grow. God Himself initiated the growth of the church by His will so that the church is called God's people which belongs to God. McGavran is the "apostle of church growth" strongly emphasizing that church growth is the 
irreplaceable goal and purpose of the church. The following statement by Donald McGavran: "We believe God desires to reconcile men to Himself through Jesus Christ in the Church of Jesus Christ. We advocate church growth not for reasons of self-aggrandizement, but because God desires it. The nature of God in Christ demands "The Church must therefore seek to be ever growing in numbers as well as in the grace and knowledge of her Lord." Jesus said "on this rock, I will build my church" (Matt. 16:18), "not merely to say 'will bring a group of people together' but $\mathrm{He}$ uses the famous term that describes God's people." the established people who are God's people are all men and women, old or young, who have been called by God to be His fellowship. Wagner said "God wants lost men and women to be found and saved." Similarly, Donald McGavran also said earlier that God wantedsheep

His lostto be found and brought back to his cage. "I will build my church" is a statement that makes it clear that God is the basis of the growth of the church, and as the founder God himself holds ownership over the church. Peter Wagner argues that "because the church belongs to God, He himself plans, shapes, establishes and determines."

Closely related to the growth of the church, whose existence has been planned, shaped and determined by God himself, Wiebracht states that God's desire is to fulfill heaven with representatives of every nation, tribe, people and language. Means, it can be concluded that the growth of the church is based on the will of God and the work of God, namely that God himself as the main source of church growth, because God wants that no human perish. The basis of the will of God who does not want anyone to perish, namely whoever believes for Jesus as the way of salvation provided by God, is the truth that explains that "the church is not a man-made institution or organization but the church of God." Historical facts that show that God wants church growth can be obtained from what is recorded in the Bible. Indeed, there are those who argue that church growth does not have any theological basis; but through a careful search in the Bible, specifically in the New Testament, namely in the book of Acts, it will be found that the growth of the church has a theological basis.
The pioneer of the church growth movement, Donald McGavnan, argues that the church growth movement is truly a theological basis. Church growth is a central theme in the book of Acts. Therefore the New Testament experts agree with the designation that this book is the History of Church Development or often referred to as the story of the History of the early Church. Therefore, the book of Acts is not infrequently used as an ideal church model. In the book written by the doctor Luke, amazing things are presented about how the congregation under the leadership of the apostles struggled to face various challenges to the growing church, both challenges originating from outside and internal challenges. When you study this book, you will also find out how the passion of the early church, the story of the heroism of the apostles and the miracles that occurred that accompanied the ministry of the apostles. What happened in the book of Acts, especially how the persistence of the apostles preached the Good News, what causes the growth of the church is certainly inseparable from the Word of Christ that was heard to them before, namely in the Gospel of Matthew 16:18, "You are Peter and on this rock I will build my church and death will not master it. "So what the apostles did that caused the church to grow as written in the book of Acts is not without foundation. The church stands on the fellowship of believers that Jesus is the Son of the living God. The church is built on the foundation of the apostles and prophets, and Jesus Christ Himself became the cornerstone. The growth of the church that is revealed in the book of Acts includes quantitative and qualitative growth. In this book, the quantity aspect of the growth of the early church is clearly seen. The early church which initially consisted of only 120 people (Acts.1: 15) increased

to 3000 (Acts 2:41), then each day the Lord increased their number (Acts 2:47), so that it became 5000 people (Acts 4: 4), even this number continues to increase where it is written the increase with "many people, everyone, almost all cities, many students, increasing in number (Acts 13: 43-44,48; 14 : 21; 16: 5; 17: 4.12). This means that the church cannot be called a church of growth when the church does not show an increase in the number of members, even if the church 
has a large building, lots of money, various activities and services.

Michael Griffiths said, "We cannot build a new temple without increasing the number of living stones." The success of the church in carrying out the task of the Lord Jesus can be seen from the increasing number of people who have believed as a result of the service of the church concerned and received shepherding from the church . Vergil Gerber said, "Although this is not the only measure for a successful church, the success of the church in carrying out its tasks can be seen in large part from the increased quantity." The early church also revealed these two aspects of growth, where "the early church was not only growing in number but also in the quality of the faith of the members of the church as noted by doctor Luke: "And they are liked by everyone. And each day, the Lord added to their number those who were saved "(Acts 2:47). The church is the fellowship of believers in Jesus Christ. He was born with the life and ministry of Jesus Christ on earth. Therefore, what is called the early church is the fellowship of the disciples of Jesus and added by several others who have claimed Jesus as Lord and are witnesses of His resurrection. This early church had a strong spirit of fellowship, service, and witness, so that the Christian faith began to spread from Jerusalem, throughout Judea, Samaria, and to the ends of the world (Acts 1: 8).

One of Jesus' disciples who was active in this gospel message was the apostle Paul. $\mathrm{He}$ preached the Gospel in almost all Roman territories in the first century, both among the diaspora Jews and non-Jews. Besides the apostle Paul, the other disciples also actively preached the gospel to the whole world. It is said that the apostle Thomas preached the gospel to India. Therefore, at the end of the first century and into the second century, a number of Christian congregations were born and grew up in all Roman territories, with different ethnic backgrounds, languages and traditions. However, these congregations recognize their unity in faith in Jesus Christ and in the task of their calling to fellowship, witness, and serve as Christian churches. So, their oneness first lies in their faith in Jesus Christ and their call to witness in the world. In the following centuries the Christian faith continued to expand into Africa and Europe. In the period of exploration of the Ocean in the late Middle Ages, the Christian faith moved from Europe and spread throughout Asia, including Indonesia. The result is the growth of a large number of local churches and congregations in Asia in general and Indonesia in particular, with diverse cultural, linguistic, cultural and lifestyle backgrounds. Doctrinally and institutionally one church can be different from another church, according to the situation and objective conditions of its environment. But essentially, these churches recognize their unity or oneness in faith in Jesus Christ and in their call to preach the gospel in the world.

What is described above, can be briefly summarized that the church's existence is the will of God, and $\mathrm{He}$ wants the church that $\mathrm{He}$ founded to grow. The church that

officially emerged after Pentecost has shown its growth as written in the book of Acts, where its growth concerns growth in quantity as well as quality. Every day God adds the number of people who believe in Jesus. The Good News about Jesus has spread from Jerusalem, throughout Judea, Samaria, and even spread throughout the earth. However, what happened after that was really contradictory, even very alarming, this is what happened in several parts of the world, such as France, Belgium, the Netherlands, Germany, Italy and other European countries, namely the countries controlled by governments that controlled hold fast to Christianity even the center of the development of Christianity is Europe. In 2002, a sociologist named Steve Bruce, in his book "God is Dead Secularization in the West" (God Is Dead Secularization in the West), said of England, "On 19th century almost all marriages were accompanied by religious ceremonies. "However, in 1971, only 60 percent of marriages in England were accompanied by religious ceremonies.

Predicted by British experts and observers, churches throughout the United Kingdom and European Countries will lead to their extinction over the deep crisis of the Christian Faith in Europe in 2040. At this time many of the world's Atheism communities that previously originated from Christianity. The unrest and turmoil of their lives of these Atheism, many of which go to convert to Islam. Churches scattered throughout the West were forced to close due to lack of congregations who were once very loyal and loyal to the church. In New Zealand and 
Australia, in Leverton, Melbourne, mosques in Westall Australia, The Monash University Australia mosque are very many churches for sale. Some were bought by Muslims and turned into mosques. Furthermore, more than 60 churches in England London, are closed every year. Hundreds of church bishops say thousands of churches are only visited by 10 congregations or less every week. A separate report from The Ecclesiological Society, the church's guardian foundation, said that 4 churches out of 4,000 churches were attended by no more than 20 members. This report indicates the possibility of closing down many churches because of the lack of followers and the lack of church income from the Christian congregation through the College and Tithing.

This incident actually has long impacted Indonesia. Many church members end up not wanting to go to church anymore, they only read the Bible themselves at home, they no longer believe in the church, in the church they are always forced to give money for collections and tithing, whereas many church members just eat hard. Many churches today no longer love their neighbors, but as fields and business venues that rely on tithing and collections as income for pastors and priests. Unfortunately, because of the greed of the preachers, often obliging and forcing the congregation to tithe (one tenth) of the entire income (including capital) of the congregation. Even though in this era, the traders' profit is only around 5 percent, so if it is taken 10 percent, it will not increase but instead it will go bankrupt. As a result, many congregants are now reluctant to go to church on Sundays, which ultimately has an impact on the income of the church itself.

Even more alarming, where there is a shift in orientation that changes surprisingly that there are 'shepherds' who are actually present as servants of God who take part in the ministry in His church. But now it actually uses the church as a 'field' of business. This is reflected in the statement of the Executive Secretary of the Greater Indonesia Christian Center, DR. Eliezer H. Hardjo Ph.D. stated that the phenomenon that is happening right now, with the mushrooming mega-church which has

assets in the form of land and buildings spread throughout Indonesia and also in several countries. In addition to investment in the form of church buildings, also in the form of schools and hotels and stock investment in the stock market. "Relatively high levels of income of servants of God and full-timer clergy have also changed the paradigm, formerly as a last alternative, but now it is first and foremost choice. No wonder many business people are also shepherds, "Measuring success, said Eliezer, in addition to the large number of congregations, the magnificent church buildings, as well as the vast network. The prestige in the abundant life of God's great servants becomes pride and dreams and is used as proof of blessing and getting God's favor.

DR. Eliezer H. Hardjo Ph.D. again stated that: "competition between churches is getting tougher, in order to maintain and increase the number of members of the congregation. The church is greater and the business of promotion. The greater or greater the number of congregations, the more blessings flowing in, it becomes a formula for success. Apparently the Lord's rebuke to the church in Laodicea was very relevant aimed at the increasingly worldly churches (Revelation 3:17), "

In relation to handling the church as a business orientation, Robert TS Nio alias Mang Ucup, in his preface to a book entitled ' The Church of Money The Church of God 'states that it cannot be denied anymore, today the church thrives like mushrooms in the rainy season. Every week there are churches that are opened or built, whether in five-star hotels or in housing estates. The church was set up like stalls in a shopping mall that competed to get as many customers as possible to meet the "sales target". Various methods and methods are applied as an attempt by the church to mutually attract sheep from pre-existing churches. With so many interesting offers and lure that lulled the heart.

Therefore it is not surprising, the results of research conducted by the Numbers Reseach Center (BRC), which is an institution led by academics, field research practitioners and pastors from evangelical circles, has conducted a survey of 4,394 church leaders spread across 34 cities / districts in Indonesia ; the results show that most church growth in Indonesia is more a transfer from other church congregations $(42.3 \%$ of the reasons for church growth) or biological growth $(28.1 \%$ of the reasons for growth). In the past 10 years, the largest number of churches surveyed (34.9\%) only at least pioneered one new church. 
There is a connection with the results of research conducted by the Senter Research Numbers (BRC) mentioned above, to satuharapan.com, in Jakarta on July 6, 2019, Director General (Dirjen) Directorate General of Community Guidance (Bimas) Christian Ministry of Religion of the Republic of Indonesia, Prof. Dr.Thomas Pentury, M.Sc., said that 50 percent of the millennial generation of Christians in Indonesia left the church. It is indeed an alarming situation, which should be a serious concern in ecclesiastical services.

Not denying the reality of church management such as managing a business, has raised a statement: 'is this the wrong way?' It should still be realized that the churches in their presence in the midst of the world always act as the arm of God in order to bring about peace in the mukabumi. In this context, the churches formulated their mission as a translation of God's mission for the world and all of its contents. Mission as a mission. It should be understood that mission is derived from the nature of God himself, not merely as

one of the activities of the church but rather a characteristic of God that God is a missionary God. That God the Father, the Son and the Holy Spirit sent the church into the world. Thus, the mission is seen as a movement of God to the world and the church is seen as a tool to carry out the mission.

The church exists because of mission and not vice versa. Participating in missions means participating in the movement of God's love for humans, because God is the source of sending love. It can be interpreted that, the church has the privilege to participate in God's mission. In reality the mission of the church is divided into two large parts which cannot be separated from one another, namely the church in its manifestation as a fellowship and the church carrying out its witness and ministry. On the one hand, in applying its mission, the church embodies a fellowship which places a major emphasis on its existence. On the other hand, the church's mission is carried out by the church by carrying out witnesses and ministries which give a major emphasis on its work.

In short, it can be said that the church carries out its mission in two directions, namely inward, the church itself with the aim of the church's growth and development towards maturity and perfection of faith as God had hoped. Second is the mission out of the church, which is by witnessing God's work to all human beings in every speech, attitude and daily behavior.

Another problem that is squeezing the church is the problem of secularism, this is a concern of Pope Paul II writes also the decline in the spiritual life of the church in Europe (and also in other western countries). Where many people live in confusion, uncertainty and hopelessness, even though physically appear to be in need. Although in ancient times the European continent was known for the symbols of the presence of Christianity, these symbols are now threatened to disappear and become traces of the past. The reason, according to the Pope, is the progress of secularism which continues to suppress and threaten the life of the Christian faith. Secularism is a view that emphasizes human physical, moral, intellectual development as the highest point, regardless of religious considerations. With the progress of this secularism, many people have difficulty implementing the values of the Gospel in their daily lives. By separating the values of faith from daily life, people strive for the advancement of human vision apart from God's vision. Secularism puts man at the center of the reality of life, replacing God's place. Humans began to assume that the truth was determined by humans, and not by God. Here arises the idea of relativism, everything is relative because it depends on human views, which can differ from one person to another. Humans begin to forget that it was not humans who created God, but on the contrary God created humans. European culture that glorifies humans as the center of the world, separated from God, makes them live as if God does not exist. This is what is called 'silent apostasy' / (total apostasy quietly). Against this attitude, Pope John Paul II exclaimed, quoting the book of Revelation, "Wake up, and strengthen what is left that is near death ... (Why 3: 2). The church in Europe is called to rise and grow in the belief that God through His Holy Spirit is always present and continues to work in the midst of human history, and God makes His Church as a flow of life that continues to flow a sign of hope for all people.

Still in relation to secularism, Theodore Roszak criticized secularism as the cause of 
"psychic strangulation so that the human spirit cannot breathe". He deplored thearrogance of reductionistscience erasing everything that was spiritual and mysterious. Actually, only a little can be measured by science. After all, without transcendent humans drag. Alvin Toffler has long reminded that the United States alone in the past few years has emerged in more than 3000 sects. Why? If not disappointment with secularism and efforts to reach transcendence. Because "The effort to reach the meaning of life is a motivating force especially in a person".

The danger of secular man is not because he is not thirsty and hungry for divine truth, but he is deceived and deceives himself that he is not thirsty and hungry. Simone Weil wrote, "The danger, that is not the soul doubts the existence of bread, but by deception he is persuaded that he is not hungry. This can only happen by deception, because the reality of soul hunger is not a belief, but a certainty. This is the name of secularism giving stones to one who seeks the bread of life, but Christ gives living water and the bread of life that is abundant. God's absence from a person's life makes him free, but at the same time he bears unlimited responsibility David Hume acknowledges that, at first I was afraid and confused by sad solitude due to my philosophy. " Sartre agreed that detachment from God resulted in him being "totally responsible in total solitude." Freedom without form or freedom without restrictions is desirable for secular humans. But this precisely backfired for him. That's the state of being lost in a sea without a beach. Sartre realizes that being separated from God is only a lump of useless lust. "To deny God and His revelations is like letting go of the foundations of life and giving away the source of meaning and value of life. In secularism, there is no cohesion of cultural binding and personal meaning. Humans become orphans of the cosmos. Not only woe, but at the same time harmful.In terms of foundation, Christianity provides the best alternative. Secularism

has preyed, even killed its victims. This is what happened in Ireland, a country that was once so proud of the elite of the Vatican Catholic Church, is considered as the last bastion of Christianity on the continent of Europe, the late Pope Paul VI in 1946 said proudly that Ireland became the most Catholic country in the world, after World War 2,
Ireland became the largest exporter of evangelizers, but who would have thought that two years ago, the country would finally have to bow to its knees. secularism. Now, the Catholic church in Ireland is just a symbol ol history to remember the remnants of Catholic glory. There was a time when the Pope's remarks were so glorified and obeyed by every individual. But now, Christianity is increasingly left by followers. May 22, 2015, is a date the Catholic Church in Europe will never forget. Their efforts to protect Ireland from the clutches of secularism failed miserably. The referendum resulted in a decision to legalize a type of 'marriage'. As many as $62 \%$ of the people of Ireland fully support the policy. Ireland turned secular, following in the footsteps of the Netherlands, Norway, England, Germany, Finland, Sweden, Belgium, France, Spain, which had already legalized LGBT-type marriages.

The European Union will be headed for total destruction. The European Union is slowly going along with time to a complete collapse. Signs of destruction are increasingly visible, and the result of deviant behavior. Christianity is dead, and is no longer the backrest of people's lives in the European Union. In the West, pastors and pastors in churches bless same-sex couples, who get married. In fact, in the UK a couple of priests do a kind of marriage. This is truly a damned act, and goes beyond animals.

Since the 1960s the existence of LGBT has demonstrated its existence in Indonesia, as reflected in its history as follows:

LGBT people with homosexual orientation and identity emerged in major cities in Indonesia in the early 20th century. In the late 1960s, the LGBT movement began to develop through organizational activities carried out by transgender women's groups, or what became known as transvestites / bencong. Mobilization of gays and lesbians occurred in the 1980s, through the use of print media and the formation of small groups throughout Indonesia. This mobilization was increasingly developed in the 1990s, including the formation of various organizations in more places. In the decade between 1980-1990 there were a number of national meetings which were followed by important developments in the LGBT movement, including the formation of alliances with various feminist organizations, sexual and 
reproductive health, pro-democracy and human rights movements, as well as academics. In 1998 the LGBT movement grew larger and broader with stronger organizing at the national level. Their programs received formal funding, as well as the use of human rights discourse to advocate for policy changes at the national level to date. In 2014 statistical data showed that the number of LGBT organizations in Indonesia was very large. They have two national networks and 119 organizations established in 28 provinces from all 34 provinces in Indonesia, varying in composition, size and age. These organizations play an active role in the field of health, publications and organizing social and educational activities. Even now they are trying to get recognition and legality from the government by adding as many members as possible to show that their existence deserves to be calculated and legally recognized. It is this phenomenon that makes social and religious organizations begin to speak out about LGBT, which in essence they reject the recognition of the existence of LGBT legally.

Other problems that occur in the church environment are shifting service orientation; in accordance with its call, the church is called to serve lost souls, but has shifted to the 'building', and this is what Dr. Merry Kolimon, Chair of the GMIT Synod. In the 70th anniversary of GMIT and the 500th anniversary of the reformed church in the spirit of renewal and change and repentance, said the Reverend Colimon, the perspective on building churches and congregations must be changed. And again, Reverend Dr. Merry Kolimon requested that the pastors not only be busy collecting money from the congregation to build a magnificent church building but forget to take care of the social, economic and HR problems of the congregation.

As a social institution, the church is called to involve itself actively in the process of empowerment, both social and economic with the aim of building a society that is capable of self-sufficiency. As salt and light and as one of the social organizations engaged in society, the church is required to be sensitive to the problems that surround it. This is where the task of the church will become more apparent in realizing the kingdom of God, namely by helping all people in need. This is in line with JC Sikkel's (1880) statement that churches can live without buildings, but churches cannot live without diaconia.

The church does not only carry out the preaching of the Word, but does and realizes the Word in the midst of people's lives. Diakonia is not just giving money. Diakonia is a call to share life and solidarity with the poor and oppressed. The aim of Dionia is to realize humanity and a new world. Because of that the diaconia must be carried out in the framework of Missio Dei, namely the presence of God's government in the world and the scope of the diaconia is not limited by the

walls of the church but covers every corner of life, both economic and political. Therefore the church must be active and creative in responding to all changes and problems in the midst of human life. In this framework, diaconia must no longer be charitable, but must be reformative and transformative at the same time.

In this study there are two independent variables or independent variables and one dependent variable or dependent variable. The independent variable is the influencing variable, while the dependent variable is the affected variable.

In this study the first independent variable is the coaching of church members. The church is a collection of people whom God has called out of this world to be His, the people belonging to God himself. God calls them in and through Jesus Christ. Where its existence consists of people from different backgrounds, both in terms of culture and level of education.

As mentioned earlier that the existence of the church is God's will, and he wants his church to grow, and therefore there is a need for fostering church members. The formation of church members is an attempt by the church to mature the church community, so that through the process of learning and experiencing continuous self-change, church members are willing and able to witness, fellowship and serve in the midst of the church and community.

Ps. Dr. Frans Pantan explained several reasons for empowering the human resources of the congregation members as follows:

1) The family, church, community and the state need citizens who have good faith, so that they are able to withstand all kinds of challenges and temptations to sin or act 
dishonestly. To answer these needs, the formation of church residents (PWG) is one of the appropriate means.

2) PWG is one of the concrete efforts of the church in carrying out the task of empowering its people, both theologically and practically relevant. It means that; from the theological aspect, the church and its citizens are equipped with the ability to interpret the truth of biblical messages precisely and correctly into the situation of a particular society or the world. This is where a weighting and precise formation of theology is needed, meaning that it can answer the struggle and questions of the Christian faith. While from the practical aspect, the formation is expected to touch all aspects of basic human equipment (in the form of multi competence) so that the church and its citizens have technical knowhow in various aspects, to overcome the concrete life problems they face.

3) Concrete state of church members as an integral part of a global society that lives and experiences fundamental changes that are fast and touch all aspects of life. In this context, PWG is very relevant to prepare church members to be ready to welcome these changes.

Lontoh and Jonathans stated that Church Community Development (PWG) is one of the essential tasks of the church which is very important to equip church members with missionary knowledge, skills and attitudes in carrying out the Church Vocation Trainer. Meanwhile, according to Alfred

Schmidt, the essence and purpose of PWG, the most important according to is that church members are given the opportunity to grow into adulthood.

Next, there is another problem that occurs in the Lord's church, where the church has begun to ignore discipleship. Discipleship is one part of the Church Community Coaching service. Discipleship may be an increasingly rare word heard from within the church. Not many churches really make discipleship the focus of their activities. Social actions, fundraising activities, seminars, commission meetings, and various other activities are even more common in the church these days. Like evangelism, discipleship seems increasingly to be an activity that is seen as unimportant, interesting, or even forgotten. The most likely reason for that is because world values have increasingly entered church teachings. It seems too comfortable with the life of a believer who is diligent in attending church, in fellowship, giving offerings, and attending several prayer meetings, and no longer has a desire or passion for evangelism and discipleship. The convenience of life makes the church indifferent to paying the price and doing what God calls the church.

In his book entitled Transforming Dicipleship, Greg Ogden stated that many church members complained that their church did not have a long-term plan for discipleship and spiritual growth. On the other hand, many church leaders lament the lack of resources to accelerate church growth and few ministers who are willing to serve in church programs. The root cause of the lack of church growth is very likely not due to a lack of concern for the congregation but may be more due to ineffective discipleship of the congregation that they already have and molded them to be committed followers of Christ.

David Wheeler and Vernon M. Whaley, in their article entitled Worship and Witness: Becoming a Great Commission Worshiper emphasized:

No doubt, indifference was killing the church. Many church members don't care about making disciples. The Scriptures describe this attitude as lukewarm (see Revelation 3:16). It is said that the opposite of love is not hatred, but ignorance. At the very least, hatred is still driven by a passion (passion). Meanwhile, apathy doesn't care enough to love. This attitude, gradually, will bring the church to separate itself from culture.

Furthermore David Wheeler and Vernon M. Whaley stressed that at this time, ignorance has become the norm for many congregations. Instead of embracing the needs of the community, instead choosing to stay far from the front line of service is instead. This attitude influences the way the church carries out discipleship. Rather than associating with the outside world to meet their needs and share the love of Christ, the church separated itself, focused on its own needs, and denounced the world for sinning. The church as the center of spiritual education for the congregation, became very important to note, why? Because the church sometimes loses identity as an instrument in the hands of God who continues teaching tasks to the congregation. The church in the phenomenon 
of the last decade experienced a lot of "decline", especially in providing excellent service in educating and teaching congregants.

The second independent variable in this study is pastoral care. Essentially pastoral care is service that reflects the care or care of God for His creation. According to Patton, the term "pastoral" refers to attitudes that care (care) and pay attention (concern). This concern, in the Bible is described as the care of the shepherd of his sheep. However, the picture of a shepherd-sheep can build a concept of dependency, where the sheep are very dependent on the shepherd. Such a picture is also often traditionally understood which precisely narrows and limits what is called pastoral care. This is evident in the view that considers that pastoral care is limited to individual and exclusive services, namely Christians or church members.

This emphasis on pastoral care for individuals and exclusives is seen, for example, in the Bons-Storm concept of shepherding. According to him, the shepherding: includes several things, namely searching and visiting members of the church one by one; preaching the word of God to the church in the midst of their personal life situation; serving the church, just as if Jesus served them; and so that they are more aware of their faith, and can realize that faith in their daily lives.

Pattison said that pastoral services directed at individuals basically did not appreciate the togetherness and social aspects that exist. Pastoral ministry cannot be limited to individuals because of many sins, sufferings, and the capacity to grow whose roots are outside of humans as individuals. Nor can pastoral ministry be aimed only at Christians. In reality, pastoral care is not done for the church, but for the world. Thus it can be understood that pastoral care is a service that not only pays attention to the relations between human beings but also human relations with God, and places God in human relations with each other. This makes pastoral ministry a valuable tool through which the church can serve human needs holistically.

Based on the background of the problem that has been explained above, the writer is interested in raising this issue in the dissertation with the title: The Effect of Church Community Development and Pastoral Services on the Growth of the Congregation of
Bethel Indonesia Church, Family Blessing Surabaya.

\section{PROBLEM IDENTIFICATION}

Based on the background of the problem outlined above, the researcher identified the problems as follows:First, God wants the church he founded to grow. Even though the church initially grew rapidly as recorded in the book of Acts, but on the way history of decline occurred both in quality and quantity. Deterioration in quality, which is marked by a decline in the moral quality of the people. This happens in several parts of the world, such as in Ireland, England, France, also in Indonesia, where the church tolerates adultery, including the practice of same-sex marriage, LBGT, and so forth. Second, secularism has threatened the life of the Christian faith. Secularism puts man at the center of the reality of life, replacing God's place. Humans began to assume that the truth was determined by humans, and not by God.

Here arises the idea of relativism, everything is relative because it depends on human views, which can differ from one person to another. Third, there has been a shift in service orientation in church management. In his calling, God calls the church to serve 'souls' so that souls (humans) benefit from it. But now the orientation has shifted to the orientation of how the church management brings financial benefits.

Fourth, another problem that is also found in ecclesiastical ministry is too busy taking care of the building (church building) and all the furniture in it. In fact, the church is more focused on liturgical services and ignorant of deaconsist services. Evangelism and discipleship services are an inseparable part of pastoral ministry, however both words are rarely heard or heard in the church. Church Community Development and Pastoral Services more serious handling is needed as part of God's call to His church.

\section{LIMITATION OF THE PROBLEM}

Based on the background and identification of the problems as explained above, in writing this dissertation the writer focuses on the problem of fostering church members and pastoral care that is associated with the growth 
of the congregation, namely the growth of the congregation of the Bethel Indonesia Family Blessing Church in Surabaya

\section{PROBLEM FORMULATION}

Based on the background of the problems mentioned above, there are several problem formulations in this study are as follows: First, does the Guidance of Church Residents and Pastoral Services affect the growth of the congregation of the Bethel Indonesia Church Family Blessing Surabaya? Second, how big is the influence of Church Community Development and Pastoral Services on the growth of the congregation of the Bethel Indonesia Church Family Blessing Surabaya?

Third, does the Guidance of Church Residents and Pastoral Services jointly affect the growth of the congregation of the Bethel Indonesia Church Family Blessing Surabaya? Fourth, how much influence do Church Coaching and Pastoral Services together have on the growth of the congregation of the Bethel Indonesia Family Blessing Church?

\section{RESEARCH OBJECTIVES}

Referring to the above problem formulation, the objectives in this study are as follows: First, it aims to describe authentic data about the influence of Church Community Development and Pastoral Services on the growth of the congregation of the Bethel Indonesia Family Blessing Church in Surabaya. Second, it aims to explain how much influence the Development of Church Residents and Pastoral Services on the growth of the congregation of the Bethel Indonesia Church Family Blessing Surabaya.

Third, and aims to present authentic data about the influence of the Coaching of Church Members and Pastoral Services together on the growth of the congregation of the Bethel Indonesia Church Family Blessing Surabaya. Fourth, and aims to explain how much influence the Coaching of Church Members and Pastoral Services together on the growth of the congregation of the Bethel Indonesia Church Family Blessing Surabaya.

\section{BENEFITS OF RESEARCH}

\section{Theoretical Benefits}

a. The results of this study may be able to increase knowledge and understanding of church coaching services and pastoral care that affect the growth of the church.

b. The results of this study can be used as a reference and or comparison of research with similar topics in the future.

2. Practical Benefits

a. For the author, this research is useful as additional knowledge related to church coaching services and pastoral care that affect the growth of the church.

b. For Church Servants, the results of this study can be used as an evaluation material for ecclesiastical services, and at the same time as motivation in serving His church. Variables

As mentioned above, in this study there are two independent variables and one dependent variable. The independent variable is a variable that influences or causes the change or the appearance of the dependent variable. While the dependent variable is a variable that is affected, or which becomes a result, because of the independent variable. The variables in this study are as follows:

\section{VARIABLES}

As mentioned above, in this study there are two independent variables and one dependent variable. The independent variable is a variable that influences or causes the change or the appearance of the dependent variable. While the dependent variable is a variable that is affected, or which becomes a result, because of the independent variable. The variables in this study are as follows:

$$
\begin{aligned}
& \mathrm{X}_{1}=\text { Guidance of Church Members } \\
& \mathrm{X}_{1}{ }^{1} \quad \text { = Koinonia } \\
& \mathrm{X}_{1}{ }^{2} \quad \text { = Diakonia } \\
& \mathrm{X}_{1}{ }^{3} \quad \text { = Marturia } \\
& \mathrm{X}_{2}=\text { Pastoral } \\
& \mathrm{X}_{2}{ }^{1} \quad \text { Services } \\
& \mathrm{X}_{2}{ }^{2} \quad \text { Shepherding } \\
& \mathrm{X}_{2}{ }^{3} \quad \text { = Visitation } \\
& \mathrm{Y}=\text { Growth of Church (Pastoral Counseling) } \\
& \mathrm{Y}^{1}=\text { Quality } \\
& \mathrm{Y}^{2}=\text { Quality }
\end{aligned}
$$


Where $\mathrm{X}_{1}{ }^{1}$ and $\mathrm{X}_{1}{ }^{2}$ and $\mathrm{X}_{1}{ }^{3}$ are the dimensions of the first independent variable. Then, $\mathrm{X}_{2}{ }^{1}$ and $\mathrm{X}_{2}{ }^{2}$ and $\mathrm{X}_{2}{ }^{3}$ are the dimensions of the second independent variable. Whereas $\mathrm{Y} 1$ and $\mathrm{Y} 2$ are dimensions of the dependent variable.

Figure 3.1.

Design of Relationship Patterns

BetweenVariables Population

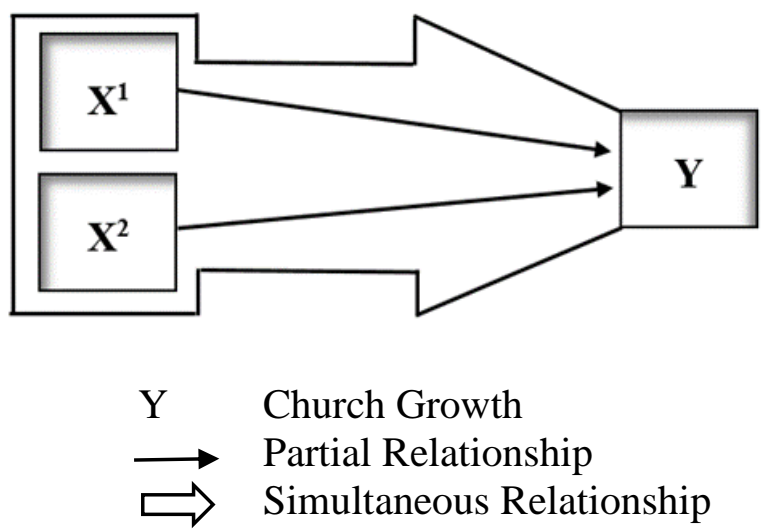

In this study, the population that was the object of research was the congregation of the Bethel Indonesia Family Blessing Church, located on Jl. Telaga Utara Blok TE-8/64 Maxwell Citra Land Surabaya area. As for the underlying reason is because in a period of less than 12 years, church growth in this church is very significant, with various service departments that have direct contact with the wider community. The sample in this study was 80 people (or $20 \%$ ) of the congregation of the Indonesian Bethel Church Family Blessing Surabaya.

\section{Characteristics of Respondents}

\begin{tabular}{|l|l|c|c|}
\hline No & Characteristics & Amount & $\begin{array}{c}\text { Percentage } \\
(\%)\end{array}$ \\
\hline & Gender : & 50 & $52 \%$ \\
& Male & $46 \%$ \\
& Female & 46 & $48 \%$ \\
& & \\
\hline & Total Respondents & $\mathbf{9 6}$ & $\mathbf{1 0 0 \%}$ \\
\hline Latest Education & 5 & $5,2 \%$ \\
Elementary School & 1 & $1,04 \%$ \\
Junior High School & 55 & $57,29 \%$ \\
Diploma & 5 & $5,2 \%$ \\
Bachelor Degree & 28 & $29,16 \%$ \\
\hline
\end{tabular}

\begin{tabular}{|l|c|c|}
\hline Bachelor Degree & 2 & $2,08 \%$ \\
\hline Total Respondents & $\mathbf{9 6}$ & $\mathbf{1 0 0 \%}$ \\
\hline Age & & \\
-16 - 40 years old & 44 & $46 \%$ \\
$\cdot 41-69$ years & 52 & $54 \%$ \\
\hline Total Respondents & $\mathbf{9 6}$ & $\mathbf{1 0 0 \%}$ \\
\hline
\end{tabular}

\section{CONCLUSIONS}

Based on the acquisition and analysis of the data it can be concluded several conclusions as follows: First, the first hypothesis in this study is the alleged influence of Church Community Development on the Growth of the Bethel Indonesian Church Family Blessing Surabaya being moderate. The results of the calculation of a simple correlation between Community Citizens Coaching (X1 ) with Church Growth (Y) found an $\mathrm{R}$ value of $0.463 \mathrm{a}$ and a positive value. That is, the magnitude of the relationship between the Coaching of Church Members to the Growth of Congregations of the Bethel Indonesia Church Surabaya Family Blessing is 0.463 in the medium category.

From the analysis also obtained R2 (coefficient of determination) of 0.215 or $21.5 \%$. This means that the contribution of the variable Guidance of Church Residents in shaping the variable of the Congregation of the Congregation of the Bethel Indonesia Church Surabaya Family Blessing is $21.5 \%$ while the remaining $78.5 \%$ is influenced by other factors outside the research model.

The significance of the Regression Test between $\mathrm{X} 1$ and $\mathrm{Y}$ shows that there is a significant relationship between the variables of church coaching (X1) to the growth of the congregation $(\mathrm{Y})$ with an $\mathrm{F}$ value of 25,683 with a value of $\alpha=0,000$ which turns out to be significant at $\alpha<0.05$. While the correlation test results showed a significant influence between $\mathrm{X} 1$ to $\mathrm{Y}$ with a $\mathrm{t}$ value of 5.068 and it turned out to be significant at $\alpha$ $<0.05$. As for the linear regression equation generated $\hat{\mathrm{Y}}=19.212+0.142 \mathrm{X} 1$. That is, each improvement of Guidance for Church Members increases once, then the Growth of the Congregation of the Bethel Indonesia Church in Surabaya Family Blessing will 
increase by 0.142 times. So based on the results of the above research, it can be concluded that the first hypothesis in this study, that the influence of church coaching on the growth of the congregation of the Bethel Indonesia Church Family Blessing Surabaya is being proven or acceptable. Second, the second hypothesis in this research is that it is assumed that the influence of Pastoral Services on the Growth of the Congregation of the Bethel Indonesian Church in Surabaya Family Blessing is being moderate. The results of a simple correlation calculation between Pastoral Services (X2) with Church Growth (Y) found a value of $\mathrm{R}$, amounting to $0.404 \mathrm{a}$ and positive value. That is, the magnitude of the relationship between Pastoral Services to the Growth of the Congregation of Bethel Indonesia Church Surabaya Family Blessing is $0.404 \mathrm{a}$ in the medium category.

From the results of the analysis also obtained the value of R2 (coefficient of determination) of 0.163 or $16.3 \%$. This means that the contribution of the Pastoral Services variable in shaping the growth variable of the Congregation of the Bethel Indonesia Church in Surabaya Family Blessing is $16.3 \%$ while the remaining $83.7 \%$ is influenced by other factors outside the research model.

The significance of the Regression Test between $\mathrm{X} 2$ and $\mathrm{Y}$ shows that there is a significant relationship between the Pastoral Services variable (X2) and the growth of the congregation (Y) with an $\mathrm{F}$ value of 18,288 with a value of $\alpha=0,000$ which is significant at $\alpha<0.05$. While the correlation test results showed a significant influence between X2 to $\mathrm{Y}$ with a $\mathrm{t}$ value of 4.277 and it was significant at $\alpha<0.05$. The linear regression equation results $\hat{Y}=19.256+0.182 \mathrm{X} 2$. That is, each improvement of Guidance for Church Members increases once, then the Growth of the Congregation of Bethel Indonesia Church Surabaya Family Blessing will increase 0.182 times.

So based on the results of the study above, it can be concluded that the second hypothesis in this study, that the influence of pastoral care on the growth of the congregation of the Bethel Indonesia Church Family Blessing Surabaya is being proven or acceptable.
Third, the hypothesis in this study is that it is assumed that the influence of Church Community Coaching and Pastoral Services together on the Growth of Congregations of the Bethel Church in Indonesia Family Blessing Surabaya is being moderate. The results of the calculation of a simple correlation between Church Community Builders (X1) and Pastoral Services (X2) with Church Growth (Y) found the value of $\mathrm{R}$, amounting to $0.488 \mathrm{a}$ and positive value. That is, the magnitude of the relationship between Church Community Coaching and Pastoral Services to the Growth of the Congregation of the Bethel Indonesian Church in Surabaya Family Blessing is $0.488 \mathrm{a}$ in the medium category.

From the analysis also obtained R2 (coefficient of determination) of 0.238 or 23.8\%. This means that the contribution of the Pastoral Services variable in shaping the growth variable of the Congregation of the Bethel Indonesia Church in Surabaya Family Blessing is $23.8 \%$ while the remaining $77.2 \%$ is influenced by other factors outside the research model.

From the Regression significance test between $\mathrm{X} 1$ and $\mathrm{X} 2$ to $\mathrm{Y}$, there was a significant relationship between the variables of Church Citizenship Development (X1) and Pastoral Services (X2) to the growth of the congregation (Y) with an $\mathrm{F}$ value of 14,512 with a value of $\alpha=0,000$ which was significant at $<0.05$. While the correlation test results showed a significant influence between $\mathrm{X} 1$ and $\mathrm{X} 2$ on $\mathrm{Y}$ with $\mathrm{t} 1$ values of 3.025 and $t 2$ of 1.685 , it was significant at $\alpha$ $<0.05$. The linear regression equation is generated $\hat{Y}=16,641+0,106 \mathrm{X} 1+0,087 \mathrm{X} 2$ It means, each improvement of Guidance of the Church Members increases once, then the Growth of the Congregation of the Bethel Indonesia Family Blessing Church in Surabaya will increase 0.106 times. And each improvement in Pastoral Services increases once, then the Growth of the Congregation of the Bethel Indonesia Church in Surabaya Family Blessing will increase by 0.087 times.

So based on the results of the above research, it can be concluded that the third hypothesis in this study, that the influence of church coaching and pastoral care on the 
growth of the congregation of the Bethel Indonesia Church Family Blessing Surabaya is being proven or acceptable.

In addition to the conclusions of the three hypotheses above, in this study the researchers also analyzed the effects of the variables $\mathrm{X} 1$ and $\mathrm{X} 2$ on the two dimensions of the $Y$ variable, namely the growth of the church in quality (Y1) and in quantity (Y2). The results of the analysis are as follows.

First, based on the calculation of a simple correlation between $\mathrm{X} 1$ and $\mathrm{Y} 1$, there is an $R$ value of $0.375 \mathrm{a}$ and is positive, which means that the magnitude of the relationship between Church Community Development for Church Growth in the quality of the Bethel Indonesia Family Blessing Surabaya Church Surabaya is $0.375 \mathrm{a}$. Thus it can be concluded that the influence of Church Community Development (X1) on the Growth of Congregations in quality The Bethel Indonesia Church Family Blessing Surabaya (Y1) "tends to be low", because the influence of Church Community Development on Church Growth in the quality of the Bethel Indonesia Church Family Blessing Surabaya is $37,5 \%$ in the low category.

Second, based on the calculation of the simple correlation between $\mathrm{X} 1$ and $\mathrm{Y} 2$ there is an $\mathrm{R}$ value of $0.463 \mathrm{a}$ and is positive; Which means, the magnitude of the relationship between Church Community Coaching on Church Growth in quantity The Bethel Indonesia Church Family Blessing Surabaya is $0.463 \mathrm{a}$. Thus it can be concluded that the influence of Church Community Development (X1) on the Growth of the Church in quantity The Bethel Indonesia Church Family Blessing Surabaya (Y2) is moderate, because the influence of Church Community Development on Church Growth in the quality of the Church Bethel Indonesia Family Blessing Surabaya is $46.3 \%$ in the medium category.

Third, Based on the calculation results of a simple correlation between $\mathrm{X} 2$ and $\mathrm{Y} 1$ there is an $\mathrm{R}$ value of $0.398 \mathrm{a}$ and is positive; Which means, the magnitude of the relationship between Pastoral Services on Church Growth in the quality of the Bethel Indonesia Church Family Blessing Surabaya is 0.398a. Thus it can be concluded that the influence of Pastoral
Services (X2) on the Growth of the Church in the quality of the Bethel Indonesia Church Surabaya Family Blessing (Y1) is likely to be low, because the influence of the Development of Church Residents on the Growth of the Church in the quality of the Bethel Indonesia Church Family Blessing Surabaya is $39.8 \%$ in the low category.

Fourth, based on the calculation of a simple correlation between $\mathrm{X} 2$ and $\mathrm{Y} 2$ there is an $\mathrm{R}$ value of $0.290 \mathrm{a}$ and is positive; Which means, the magnitude of the relationship between Pastoral Services to the Growth of the Church in quantity the Bethel Indonesia Church Family Blessing Surabaya is 0.290a. Thus it can be concluded that the influence of Pastoral Services (X2) on the Growth of the Church in quantity The Bethel Indonesia Church Family Blessing Surabaya (Y2) is likely to be low, because the influence of Church Community Development on Church Growth in the quality of the Bethel Indonesia Church Family Blessing Surabaya is $29.0 \%$ in the low category.

\section{REFERENCES}

[1]. George W. Peters, Teologia Pertumbuhan Gereja(Malang: Gandum Mas, 2002)

[2]. Louis Berkhof, Teologi SistematikaDoktrin Gereja (Jakarta: Lembaga Reformed Injili Indonesia, 1997)

[3]. Northrop, Chuck, Biblically Speaking About the ChurchCharles A. Northrop Jr., 1997

[4]. Charles C. Ryrie. Teologi Dasar, Buku 2(Yogyakarta: Yayasan ANDI, 2000)

[5]. G.C. Van Niftrik dan B.J. Boland, Dogmatika Masa Kini(Jakarta: BPK Gunung Mulia, 2001)

[6]. Louis Berkhof,Teologi Sistematika.Volume 5(Surabaya: Lembaga Reformed Injili Indonesia, 1997)

[7]. Henry Clarence Thiessen,Teologi Sistematika (Malang: Gandum Mas, 2003) 
[8]. Joel Comiskey, Menuai Tanpa Batas (Jakarta: Metanoia, 2003)

[9]. Boland, B.J., and G.C. Van Niftrik, Dogmtika Masa Kini (Jakarta: BPK.Gunung Mulia,1999)

[10]. R.J. Porter, Katekisasi Masa Kini (Jakarta: Cempaka Putih, 1984),

[11]. Jan S. Aritonang, Berbagai Aliran di Dalam dan Di Sekitar Gereja(Jakarta: BPK Gunung Mulia, 1994)

[12]. L. Rost, H. Schlier,"Ekklesiologie des Neuen Testaments", in Mysterium Salutis 4, I (1972)

[13]. John Seamands, dalam artikelnya "What Mcgavran's Church Growth Thesis Means" terdapat dalam https://missionexus.org/whatmcgavrans-church-growth-thesis-means/.

[14]. Donald A McGAvran, Church Growth and Christian Mission (New York: Harper and Row, 1965 )

[15]. D.A. Carson, Gereja Zaman Perjanjian Baru Dan Masa Kini (Malang: Gandum Mas, 1997)

[16]. C. Peter Wagner, Pertumbuhan Gereja Dan Peranan Roh Kudus (Malang: Gandum Mas, 1996)

[17]. Donald McGavran dalam C. Peter Wagner, Strategi Perkembangan Gereja (USA: Gospel Literature International)

[18]. C. Peter Wagner, Strategi Perkembangan Gereja (Malang: Gandum Mas, 2003)

[19]. Dean Wiebracht, Menjawab Tantangan Amanat Agung (Yogyakarta: Andi, 1992)

[20]. Vergil Gerber, Pedoman Pertumbuhan Gereja/Penginjilan (Bandung: Yayasan Kalam Hidup,1973)

[21]. Sumber data: Summary Seminar Hasil Temuan Survei Nasional Dinamika Gereja di Indonesia (BRC-30 Januari 2018). Terdapat juga di https://selisip.com/2018/02/data-dankata-terbaru-gereja-di-indonesia-1/
[22]. Melki Pangaribuan "Dirjen Kristen: 50\% Generasi Milenial RI Tinggalkan Gereja" terdapat dalam http://www.satuharapan.com/readdetail/read/dirjen-kristen-50-generasimilenial-ri-tinggalkan-gereja.

[23]. Sumber data: Summary Seminar Hasil Temuan Survei Nasional Dinamika Gereja di Indonesia (BRC-30 Januari 2018). Terdapat juga di https://selisip.com/2018/02/data-dankata-terbaru-gereja-di-indonesia-1/

[24]. Melki Pangaribuan "Dirjen Kristen: 50\% Generasi Milenial RI Tinggalkan Gereja" terdapat dalam http://www.satuharapan.com/readdetail/read/dirjen-kristen-50-generasimilenial-ri-tinggalkan-gereja

[25]. David J. Bosch, Transformasi Misi Kristen (Jakarta: BPK Gunung Mulia 1999

[26]. Badan Pekerja Majelis Sinode GKI, Tata Gereja GKI (Jakarta, 2003)

[27]. Thedore Roszak, Where the Wasteland Ends (New York: Anchor, 1973)

[28]. Thedore Roszak,164-165.

[29]. Simone Weil, Waiting for God (New York: Putnam, 1951)

[30]. Jean Paul Sartre, Being and Nothingness, terj. Hazel E. Barnes (London: Methuen, 1957)

[31]. C.I. Glicksber, Modern Literature and the Death of God(The Hague, 1966)

[32]. USAID-UNDP. Hidup Sebagai LGBT di Asia: Laporan Nasional Indonesia(Jakarta: USAID-UNDP, 2014)

[33]. [1] Abineno, J.L. Ch. Percakapan Pastoral dalam Praktik. Jakarta: BPK Gunung

Mulia, 1982.

[2] Abineno, J.L. Ch. Pernikahan. Jakarta: BPK Gunung Mulia, 1983. 
[3] Abineno, J.L. Ch.Penggembalaan. Jakarta: Badan Penerbit Kristen, 1987.

[4] Abineno. J.L. Ch. Pelayanan dan Pelayan Jemaat Dalam Perjanjian Baru.

Jakarta: BPK Gunung Mulia, 1991.

[5] Abineno, J.L. Ch. Pedoman Praktis Untuk Pelayanan Pastoral. Jakarta:BPK

Gunung Mulia, 2012.

[6] Achmadi, Abu dan Narbuko Cholid, Metodologi Penelitian, Jakarta: Bumi

Aksara, 2013.

[7] Aldrich, Joseph A. Life-Style Evangelism. Portland, Oregon: Multnomah Press,

1982.

[8] Arifin, M. Pelaksanaan Bimbingan

Penyuluhan Agama. Jakarta: Golden Terayn

Press, 1998.

[9] Arikunto,Suharsimi. Metodologi

Penelitian.Jakarta: PT. Rineka Cipta, 2002.

[10] Aritonang, Jan S. Berbagai Aliran di

Dalam dan Di Sekitar Gereja. Jakarta:

BPK Gunung Mulia, 1994.

[11] Artanto, Widi. Menjadi Gereja Misioner. Yogyakarta: Kanisius, 1997.

[12] Balz, Horst \&Gerhard Schneider, Exegetical Dictionary Of The New Testament

(Volume 2). Michigan: William B. Eerdmans Publishing Company Grand Rapids,

1991; reprint ed., 2000.

[13] Barclay, William. Pemahamn Alkitab

Sehari-hari: Surat-surat Yohanes dan Surat

Yudas, Jakarta:BPK Gunung Mulia, 1990.

[14] Beek, Aart Van. Pendampingan Pastoral, (Jakarta: BPK Gunung Mulia, 2003.
[15] Berkhof, Louis.Teologi

Sistematika.Volume 5.Surabaya: Lembaga

Reformed

Injili Indonesia, 1997.

[16] Berkhof, Louis.Teologi Sistematika-

Doktrin Gereja. Jakarta: Lembaga

Reformed Injili Indonesia, 1997.

[17] Berkhof, Louis. dalam bukunya Teologi Sistematika.Volume 5. Surabaya:

Lembaga Reformed Injili Indonesia, 1997.

[18] Berkhof dan Dr. I.H. Enklaar, Sejarah Gereja.Jakarta: BPKGunung Mulia

(cetakan ke-5), 1986.

[19] Boland, B.J., and G.C. Van

Niftrik.Dogmtika Masa Kini, Jakarta:

BPK.Gunung

Mulia,1999.

[20] Browning, W.R.F. Kamus Alkitab. Jakarta: BPK Gunung Mulia, 2010.

[21] Bosc, David J. Transformasi Misi

Kristen. Jakarta: BPK Gunung Mulia 1999.

[22] Badan Pekerja Majelis Sinode GKI. Tata Gereja GKI. Jakarta, 2003.

[23] Bons-Storm, Maria. Apakah

Penggembalaan itu? Jakarta: BPK Gunung Mulia,

2008.

[24] Boland, B.J., and G.C. Van Niftrik.

Dogmtika Masa Kini. Jakarta: BPK.Gunung

Mulia, 1999.

[25] Carson, D.A. Gereja Zaman Perjanjian

Baru Dan Masa Kini. Malang: Gandum

Mas, 1997.

[26] Choeldahono, Novembri. "Gereja, Lembaga Pelayanan Kristen dan Diakonia 
Transformatif” dalam Agama Dalam Praksis, Th. Kobong (Ed.). Jakarta: BPK.

Gunung Mulia, 2003.

[27] Clinebell, Howard.Tipe-tipe Dasar

Pendampingan dan Konseling

Pastoral.Yogyakarta: Penernit Kanisius, 2002.

[28] Coleman, Robert E. Rancangan Agung

Penginjilan, Bandung: Kalam Hidup, tt.

[29] Coolin, Gerry R. Konseling Kristen Yang Efektif. Malang: SAAT, 1996.

[30] Colson, Howard P. dan Raymond M.

Rigdon, Understanding Your

Church's Curriculum.Nashville: Broadmann Press, 1981.

[31] Cowles, Robert. Gembala Sidang.

Cetakan keempat. Bandung: Kalam Hidup,

1993.

[32] Cully, Iris V. The Bible In Christian Education, (Augsburg: Fortress

Publisher,2006.

[33] Cully, Iris V. dan Cully, Kendig Brubaker (ed.). Harper's Encyclopedia of

Religious Education. (San Fransisco: Harper and Row Publishers, 1990), 357.

[34] Dainton, Martin B. Gereja dan Bergereja. Jakarta: Yayasan Komunikasi Bina

Kasih/OMF, 2002.

[35] Depdikbud: Kamus Besar Bahasa Indonesia. Jakarta: PT. Balai Pustaka, 1989.

[36] DeGenova, M.K.\& Rice, P. (Human

Intimacy: Marriage, The Family and

It'sMeaning New Edition. Boston: McGraw Hill, 2005.

[37] Dever, Mark. Sembilan Tanda Gereja Yang Sehat. Terjemahan, Jakarta:
Momentum, 2008.

[38] Douglas, J.D. peny. Ensiklopedi Alkitab Masa Kini, (Jakarta: Yayasan

Komunikasi Bina Kasih/OMF, 1992.

[39] Ellis, D.W. Model-model Penginjilan Yesus Suatu Penerapan Masa Kini.

Malang: Gandum Mas, 2003.

[40] Ensiklopedia Alkitab Masa Kini (Jilid 1), ed. S.v. "Berita, Pemberitaan." By

R.H. Mounce. (Jakarta: Yayasan Komunikasi Bina Kasih/OMF, 1995; Reprint ed.

2000.

[41] Ganggel, Kenneth O. Membina

Pemimpin Pendidikan Kristen, (Malang:

Gandum Mas, 1996.

[42] Gerber, Vergil, Pedoman Pertumbuhan Gereja/Penginjilan. Bandung: Yayasan

Kalam Hidup, 1973.

[43] Gerkin, Charles. Konseling Pastoral dalam Transisi. terj. Adji Sutama.

Kanisius: Yogyakarta, 1992.

[44] Ghozali, Imam. Aplikasi Analisis

Multivariate dengan SPSS. (Semarang: Badan

Penerbit UNDIV, 2005.

[45] Gunadi, Paul.Seri Psikologi Praktis Seks Pra Nikah. Malang: Penerbit

Seminari Alkitab Asia Tenggara, 2001.

[46] Gunawan, Agung. "Pemuridan dan Kedewasaan Rohani”, Jurnal

Theologia Aletheia, Vol. 19 No. 12 Maret 2017:6. Diakses darihttp://sttaletheia.ac.id/wpcontent/uploads/2017/04/Pemuridan-danKedewasaan-Rohani.pdf 
[47] Guthrie, Donald. Teologi Perjanjian Baru 3: Eklesiologi, Eskatologi, Etika.

Jakarta: BPK Gunung Mulia, 2006.

[48] Glicksber, C.I. Modern Literature and the Death of God. The Hague, 1966.

[49] Graham, Billy. Beritakan Injil, Cetakan kedua. Diterbitkan kerjasama antara:

Lembaga Literatur Baptis dan Yayasan ANDI, 1995.

[50] Griffiths, Michael. Gereja dan Panggilan Masa Kini. Jakarta: BPK Gunung

Mulia, tt.

[51] Hadisubrata, M.S. Keluarga Dalam Dunia Modern. Jakarta: BPK Gunung

Mulia, 2008.

[52] Hadiwijono, Harun. Iman Kristen. Jakarta: BPKGunung Mulia, 2000.

[53] Henrichsen, Walter A. Cara Melatih Murid Kristus. Cetakan ketiga. Bandung:

Kalam Hidup, tt.

[54] Hiltner, Seward. Preface to Pastoral Theology. Nashville: Abingdon Press,

1958.

[55] Hiltner, Seward. Pastoral Counseling:How Every Pastor Can Help People to

Help Themselves. Nashville: Abingdon, 1976.

[56] Hooijdonk, P.G. van.Batu-Batu Yang Hidup. Yogyakarta: Kanisius, 1996.

[57] Hutagalung, Stimson.Jurnal Koinonia, Volume 9, Nomor 1, Mei 2015.

[58] Hunter, Rodney J. et. Al., Dictionary of Pastoral Care and Counselling.

Nashville: Abingdon Press, 1990.
[59] Iskandar, Metodologi Penelitian

Pendidikan dan Sosial Kuantitatil dan

Kualitatif, Jakarta: Gaung Persada Press, 2009.

[60] Ismanil, Andar.Ajarlah Mereka Melakukan. Jakarta: BPK Gunung Mulia, 1980.

[61] Ismail, Andar. Selamat Natal - 33 Renungan tentang Natal. Jakarta: BPK

Gunung Mulia, 1997.

[62] Ismail. Andar. Awam dan Pendeta: Mitra Membina Gereja. Jakarta: BPK

Gunung Mulia, 2000.

[63] Ismail, Andar. Ajarlah Mereka

Melakukan. Kumpulan Karangan Seputar

Pendidikan Agama Kristen. Jakarta: BPK Gunung Mulia, 2003.

[64] Jacob, Beate dkk.Penyembuhan yang Mengutuhkan. Yogyakarta: Kanisius,

2003.

[65] Janets dan Muhammad Ansar dalam “Akuntabilitas Dalam Perspektif Gereja

Protestan: Studi Fenomenologis Pada Gereja Protestan Indonesia Donggala Jemaat

Manunggal Palu." Simposium Nasional Akuntansi XIV Aceh, 2011.

[66] Jenson, Ron dan Jim Stevens, Dinamika Pertumbuhan Gereja. Malang: Gandum

Mas, 2000.

[67] Jenson, Ron\& Stevens, Dinamika

Petumbuhan Gereja. Malang: Gandum Mas,

2004.

[68] Joel Comiskey, Menuai Tanpa Batas. (Jakarta: Metanoia, 2003), 61.

[69] Josef Purnama Widyatmaja, Yesus Dan Wong Cilik: Praksis Diakonia 
Tranformatif dan Teologi Rakyat di Indonesia. Jakarta: PT. BPK Gunung Mulia,

2010.

[70] Kamus Besar Bahasa Indonesia (KBBI) Kamus versi online.

https://kbbi.web.id/nikah. diakses tanggal 9 Mei 2019.

[71] Kehidupan Orang Percaya 1, Berakar. Buku Pedoman Pembinaan Warga

Gereja. Diterbitkan oleh Departemen Teologia Badan Pekerja Sinode Gereja Bethel

Indonesia. Cetakan I Tahun 2004.

[72] Kehidupan Orang Percaya 2, Bertumbuh. Buku Pedoman Pembinaan Warga

Gereja. Diterbitkan oleh Departemen Teologia Badan Pekerja Sinode Gereja Bethel

Indonesia. Cetakan I Tahun 2004.

[73] Kehidupan Orang Percaya 3, Berbuah. Buku Pedoman Pembinaan Warga

Gereja. Diterbitkan oleh Departemen Teologia Badan Pekerja Sinode Gereja Bethel

Indonesia, 2005.

[74] Kennedy, D. James. Ledakan Penginjilan. Jakarta: EE Internasional III, t.t..

[75] Kerlinger, Asas-Asas Penelitian Behaviour. Edisi 3, Cetakan 7. Yogyakarta:

Gadjah Mada University Press, 2006.

[76] Lassor, W.S. Pengantar Perjanjian Lama 1. Jakarta: BPK. Gunung Mulia,

2001.

[77] Lenga, Daniel.Pertumbuhan Gereja. Jakarta: Diktat, 2003.

[78] Liddell, Henry George; Scott, Robert (1889). An Intermediate Greek-English
Lexicon [Leksikon Yunani-Inggris Tingkat Menengah]. Oxford: Clarendon Press.

ISBN 0-19-910206-6. Diakses tanggal 18-062019. Pukul 12.46.

[79] Loekmono, Lobby. Konseling

Pernikahan: Bibliotherapy. Salatiga: Pusat

Bimbingan UKSW, 1989.

[80] Lontoh, S W. dan Hallie Jonathans.

Bahtera Guna Dharma GPIB. Jakarta: BPK

Gunung Mulia, 2014.

[81] Lukman,Titus. Keluarga Kristen, (Diktat). Tanjung Enim: STTE, 1998.

[82] Maitimoe, D.R. Membina Jemaat Misioner. Jakarta: BPK Gunung Mulia, 1983.

[83] Marbun, Purim. (Departemen Pendidikan dan Latihan) BPH GBI. Sebagaimana

terpaparkan dalam

http://www.beritabethel.com/artikel/detail/92.

[84] McGavran, Donald A. dalam C. Peter Wagner. Strategi Perkembangan Gereja.

(USA: Gospel Literature International.

[85] Noordegraaf, A.Orientasi Diakonia Gereja. Jakarta: BPK Gunung Mulia, 2004.

[86] Nurihsan, A. Junika. Landasan Bimbingan dan Konseling. Bandung: PT.

Remaja Rosdakarya, 2005.

[87] Ogden, Greg. Transforming Dicipleship. (Pemuridan yang Mengubahkan)

Literatur Perkantas Jawa Timur, ISBN: 978602-1302-01-9, Cetakan Pertama:

Februari 2014.

[88] Packer, J.I. Evangelism And The Sovereignty of God.Surabaya: Momentum,

2003. 
[89] PC Bible Version 5. Software Alkitab.

Bible Knowledge Commentary/New

Testament. Copyright @ 1983, 2000 Cook

Communications Ministries. All rights

reserved.

[90] Peace, Richard.Small Group Evangelism.

Downers, Illinois: Intervarsity Press,

1985.

[91] Pengajaran Dasar Gereja Bethel

Indonesia. Jakarta: Departemen Theologia

Badan Pekerja Harian Gereja Bethel

Indonesia, 2010.

[92] Peters, George W. Teologia Pertumbuhan Gereja.Malang: Gandum Mas, 2002.

[93] Porter, R.J. Katekisasi Masa Kini. Jakarta: Cempaka Putih, 1984.

[94] Prasetyo, Widi, et al. "Measuring the Quality of God's Servants According to Acts 6: 3 At the Surabaya City Tabernacle Pentecostal Church." Journal KERUGMA 2.1 (2019): 2433.

[95] Richards, Lawrence O.A Theology of Christian Education. New York: Mc Graw

Hill Book Company, 1975.

[96] Robertson, Roy. Pemuridan Dengan

Prinsip Timotius. Yogyakarta: Yayasan $I$

ANDI, 1995.

[97] Robinson, Darrell W. Kehidupan Gereja

Yang Utuh. Bandung: Lembaga

Literatur Baptis, 2004.

[98] Rumiyati, Rumiyati, et al. "Pengaruh

Kepemimpinan Hamba Tuhan Dalam

Pertumbuhan Kerohanian Jemaat Gereja GPdI 'Zion'Krebet, Tembalang, Wlingi-Blitar."

Journal Kerusso 3.2 (2018): 9-19.

[99] Schmidt, Alfred. Kawan Sekerja Allah. Jakarta: BPK Gunung Mulia, 1983.
[100] Selan, Ruth F. Pedoman Pembinaan Warga Jemaat. Bandung: Kalam Hidup, 2000.

[101] Senduk, H.L. Pelayan Tuhan, Cetakan ke-20.Jakarta: Yayasan Bethel, 2009.

[102] Sihombing, Lotnatigor. Kultus dan Kultur. Batu, Malang: Sekolah Tinggi

Theologia I-3, 1997.

[103] Sihombing, Mori. "Koinonia dan Keuangan Gereja yang Sehat (HKBP” dalam

buku Felloship Through Stewardship (Tinjauan Teologis Mengenai Persekutuan dan

Penatalayanan), (Pematangsiantar: Lembaga Studi Agama dan Pembangunan

[L.SAPA], 2014.

[104] Sihombing, Riana Udurman, and Rahel Rati Sarungallo. "Deskriptif Penggembalaan Yang Sehat Menurut Kitab Titus Terhadap Pertumbuhan Jemaat GPSI Wilayah I." Journal KERUSSO 4.2 (2019): 1-9.

[105] Sidjabat, B.S.Strategi Pendidikan Kristen. Yogyakarta: Yayasan Andi, 1996.

[106] Sidjabat, B.S. Pendewasaan Manusia Dewasa. Bandung: Kalam Hidup, 2014.

[107] Simbiring, Margaret.Rencana Allah bagi Rumah Tangga Kristen. Bandung:

Yayasan Kalam Hidup, 1978.

[108] Singgih, Emanuel Gerrit. Hakikat Gereja yang Melayani. Dalam Andaru

Satnyoto (Ed.), Diakonia, Tantangan Pelayanan Gereja Masa Kini. Yogyakarta:

LPM UKDW, 1992.

[109] Sitompul, Einar. Gereja Menyikapi Perubahan. Jakarta: PT. Gunung Mulia,

2004. 
[110] Soetarman, Mulai dari Musa dan Segala

Nabi. Jakarta: BPK Gunung Mulia, 2003.

[111] Strong, James. Strong's Exhaustive

Concordance of The Bible. Iowa: Riverside

BOOK and Bible House Iowa Falls, tt.

[112] Subeno, Sutjipto.Indahnya Pernikahan

Kristen. Surabaya: Momentum, 2008.

[113] Sugiyono. Metode Penelitian

Pendidikan: Pendekatan Kuantitatif,

Kualitatif,

dan R\&D. Bandung: Alfabeta, 2012.

[114] Sukamadiarti, Pendidikan dan Perilaku

Pacaran dikalangan Remaja. Jakarta:

Penerbit Grafindo, 2007.

[115] Sumiyatiningsih, Dien. Mengajar dengan Kreatif dan Menarik. Yogyakarta:

Andi, 2009.

[116] Susabda, Yakub B. Pastoral

Konseling.Malang: Gandum Mas, 1983.

[117] Susanto, Daniel. "Pelayanan Pastoral Holistik”, dalam Daniel Susanto (ed.),

Sekilas Tentang Pelayanan Pastoral di Indonesia. Jakarta: Majelis GKI Menteng

Jakarta, 2010.

[118] The American Heritage Dictionary of the English Language (edisi ke-4th).

Bartleby. 2000.

[119] Tomala, Magdalena. Konselor Kompeten. Jakarta: YT Leadership Foundation,

2000.

[120] Tomatala, Yakub. Teologi Misi. Jakarta: YT Leadership Foundation, 2005.

[121] Tong, Stephen, Kerajaan Allah, Gereja dan pelayanan. Surabaya: Momentum,
2010.

[122] Tuhumury, P. Strategi Pelayanan Sel.Bandung: Yayasan Kalam Hidup, 2001.

[123] Tuhumury, P. Pembinaan Warga

Jemaat. Makassar: STT Jaffray, 2003.

[124] Wagner, C. Peter. Strategi

Perkembangan Gereja. Malang:Yayasan

Penerbit

Gandum Mas, 1996.

[125] Wagner, C. Peter.Gereja-gereja Rasuli Yang Baru. Jakarta: Yayasan

Pekabaran Injill“Immanuel“, 2001

[126] Warren, Rick.Pertumbuhan Gereja Masa Kini: Gereja yang mempunyai Visi-

Tujuan.Malang:Gandum Mas, 2000.

[127] Warren dan Howard.Memimpin Gereja Secara Mantap-Petunjuk Praktis untuk

Gembala Sidang. Bandung: Lembaga

Literatur Baptis, 2003.

Wongso, Peter.Tugas Gereja Misi Masa Kini.

Malang: Seminari Alkitab Asia

Tenggara, April 1981.

[128] Wongso, Peter.Teologi Penggembalaan. Malang: Seminari Alkitab, 1983.

[129] Zaluchu, Julianus. "Profil Rasul Paulus Dalam Surat 1 Korintus Dan

Relevansinya Bagi Hamba-Hamba Tuhan Di Gereja Pantekosta di Indonesia

Rungkut Surabaya." Journal KERUSSO 4.2 (2019): 10-22.

[130] Zuriah, Nurul.Metodologi Penelitian Sosial dan Pendidikan. Jakarta: Bumi Aksara, 2002. 